\title{
Glycogenosis Due to Liver and Muscle Phosphorylase Kinase Deficiency
}

\author{
N. BASHAN, T. C. IANCU, A. LERNER, D. FRASER, R. POTASHNIK, AND S. W. MOSES \\ Pediatric Research Laboratory, Soroka Medical Center, Faculty of Health Sciences, Ben-Gurion University of Negev, \\ Beer-Sheva, and Department of Pediatrics, Carmel Hospital, Haifa. Israel
}

\section{Summary}

A four-year-old Israeli Arab boy was found to have glycogen accumulation in both liver and muscle without clinical symptoms. Liver phosphorylase kinase (PK) activity was $20 \%$ of normal, resulting in undetectable activity of phosphorylase $a$. Muscle PK activity was about $25 \%$ of normal, resulting in a marked decrease of phosphorylase $a$ activity.

Two sisters showed a similar pattern, whereas one brother had normal PK activity. The patient's liver protein kinase activity was normal. Addition of exogenous protein kinase did not affect PK activity, whereas exogenous PK restored phosphorylase activity to normal.

These findings indicate that these patients are affected by a rare variant of PK deficiency, which involves both muscle and liver and which apparently is not sex linked. It is possible that this defect represents an unusual mutation of a subunit of the phosphorylase kinase enzyme.

\section{Speculation}

Various mutations of the gene coding for phosphorylase kinase are located on different chromosomes, leading to specific tissue involvements and different modes of inheritance.

Phosphorylase, the rate-limiting enzyme of glycogenolysis, is activated by phosphorylase kinase. Phosphorylase kinase (ATP: phosphorylase phosphotransferase, EC 2.7.1.38), after being activated by protein kinase, catalyses the conversion of phosphorylase $b$ to phosphorylase $a$ and thus stimulates the mobilization of glycogen.

Glycogen storage disease can occur as a result of various enzymatic defects along the pathway of glycogen breakdown. Abnormal glycogenolysis in the liver and/or muscle may be due to a deficiency of phosphorylase $a$ (S) $3^{\prime}: 5^{\prime}$ cyclic adenosine monophosphate- (cyclic AMP) dependent protein kinase (14) or phosphorylase kinase activities $(13,16)$. Liver phosphorylase kinase deficiency (which has been classified by various authors as type VIa (15), VIII (9), and IX (10) is inherited either as an Xlinked $(14,16)$ or as an autosomal recessive disorder $(11,12)$.

All cases reported so far had either undetectable or very low liver phosphorylase kinase activity, but normal enzyme activity in their muscle (20-22). Muscle phosphorylase kinase deficiency has not yet been described in man, but has been observed in I strain mice (2). In these animals, the skeletal muscle phosphorylase kinase is severely deficient (7), whereas liver phosphorylase kinase activity is normal.

This paper described findings in a family with liver and muscle phosphorylase kinase deficiency. The condition is apparently inherited in an autosomal recessive manner.

\section{PATIENTS AND METHODS}

A four-year-old Israeli Arab boy (H. M.) who was admitted for an acute upper respiratory infection, was found to have marked hepatomegaly. The family history disclosed that two sisters were similarly affected, whereas one older brother was apparently healthy.

Past history was unremarkable. The patient's height was below the third percentile for his age in contrast to a normal weight. He had a doll face and a protuberant abdomen. The liver was palpable $9 \mathrm{~cm}$ below the costal margin. Slight muscular hypotonia and weakness were noticeable with normal tendon reflexes. He had slightly abnormal liver function tests, a fasting blood sugar of 72 $\mathrm{mg} \%$, a normal glucagon test, and no lactic acidemia or uricemia but slight lipidemia. Electronmicroscopic studies of a liver biopsy revealed marked deposition of glycogen. Biochemically, he had an abnormal accumulation of glycogen $17 \mathrm{~g} / 100 \mathrm{~g}$ wet weight in liver, and $1.9 \mathrm{~g} / 100 \mathrm{~g}$ wet weight in muscle.

Liver and muscle specimens, obtained by open biopsy, were quickly frozen at $-20^{\circ} \mathrm{C}$. The tissues were analyzed for glycogen concentration as described by Johnson et al. (17). Activities of the following hepatic enzymes were measured by conventional methods: glucose-6-phosphatase and amylo-1.6-glucosidase (24), total, active phosphorylase, and phosphorylase phosphatase (23): synthetase, total and active (4); $3^{\prime}: 5^{\prime}$-cyclic AMP-dependent protein kinase (6). Phosphorylase kinase activity using exogenous phosphorylase $b$ was determined by a modified method of Krebs (18): $2 \mathrm{mg}$ of liver or muscle homogenate in $50 \mathrm{mM}$ sodium glycerophosphate, $\mathrm{pH} 7.0$, were incubated in a final volume of 1 ml containing $1 \mathrm{mg}$ phosphorylase $b, 12 \mu$ moles ATP, $20 \mu$ moles magnesium acetate, $20 \mu$ moles ammonium sulfate and $0.5 \mu$ mole of cyclic AMP, at a final pH of 6.8. Phosphorylase $a$, formed as a function of time during incubation was assayed as described (23).

All substrates and enzymes were purchased from Sigma Chemicals Co., St. Louis, MO. $\left[U-{ }^{14} \mathrm{C}\right]$ glucose, $\left[U^{1{ }^{14}} \mathrm{C}\right]$ glucase-l-phosphate, and $\left[U-{ }^{14} \mathrm{C}\right]$ uridine diphosphoglucose were obtained from Radiochemical Center Amersham.

\section{RESULTS}

\section{GLYCOGEN METABOLISM IN THE LIVER OF H. M.}

The activities of liver glucose-6-phosphatase, amylo-1,6-glucosidase, total phosphorylase, and glycogen synthase were normal, whereas phosphorylase $a$ activity was zero (Table 1 ). Inasmuch as total phosphorylase was normal and phosphorylase $a$ was undetectable, all the activity of phosphorylase had to reside in the $b$ form. This suggests the presence of a defect in the activation mechanism of phosphorylase $b$. Liver phosphorylase kinase activity, using exogenous phosphorylase $b$, showed about $20 \%$ activity of normal (Fig. 1A). Incubation of concentrated normal liver homogenate $(50 \mathrm{mg} / \mathrm{ml})$ at $25^{\circ} \mathrm{C}$ resulted, as expected. in an inactivation of phosphorylase $a$, whereas in the patient's liver homogenate no phosphorylase $a$ activity was detected during similar incubation conditions. However, after the addition of ATP-Mg, a rapid activation of the endogenous phosphorylase $b$ in the patient's liver as well as the control liver occurred (Fig. 2).

The $\mathrm{pH}$ profile of phosphorylase kinase activity from $\mathrm{pH} 6.8$ to 8.6 differs between the active and the inactive form of the enzyme 
(3). Therefore, liver phosphorylase activity was measured at various $\mathrm{pH}$ values (Fig. $3 A$ ).

The ratio between the activity at $\mathrm{pH} 8.6$ to 6.8 is about 1.7 in the control liver and 2.1 in the patient's liver which indicates that irrespective of the total activity which was markedly decreased in the patient the proportion of phosphorylase kinase $a$ to $b$ of the patient approximates the ratio found in the normal control.

Protein kinase deficiency was ruled out as the activity of patient's protein kinase on exogenous histone was normal (Table 1), and the addition of exogenous protein kinase to the liver homogenate had no effect on phosphorylase kinase activity (Fig. 4). Addition of exogenous phosphorylase kinase (from rabbit muscle) restored the activation of phosphorylase $b$ (Fig. 4), demonstrating that this patient lacks liver phosphorylase kinase activity. To exclude the presence of an inhibitor, homogenate from the patient's liver was added to normal liver homogenate. No inhibition of activity was noted (Table 2 ).

Table 1. Activities of liver enzymes

\begin{tabular}{|c|c|c|}
\hline & H. M. & Control \\
\hline Phosphorylase $a(\mu \mathrm{moles} / \mathrm{g} / \mathrm{min})$ & 0 & 27.3 \\
\hline $\begin{array}{l}\text { Total Phosphorylase }(a+b) \\
(\mu \mathrm{moles} / \mathrm{g} / \mathrm{min})\end{array}$ & 120 & 120 \\
\hline $\begin{array}{l}\text { Phosphorylase phosphatase } \\
(\mu \mathrm{moles} / \mathrm{g} / \mathrm{min})\end{array}$ & 1.85 & 2.0 \\
\hline Protein kinase-cyclic AMP & 0.09 & 0.11 \\
\hline $\begin{array}{l}(\mu \mathrm{moles} / \mathrm{mg} / \mathrm{min})+\text { cyclic } \\
\text { AMP }\end{array}$ & 0.32 & 0.32 \\
\hline Synthetase $a(\mu \mathrm{moles} / \mathrm{min} / \mathrm{g})$ & 0.07 & 0.065 \\
\hline Synthetase $a+b(\mu$ moles $/ \mathrm{min} / \mathrm{g})$ & 2.4 & 2.7 \\
\hline $\begin{array}{l}\text { Glucose-6-phosphatase ( } \mu \text { moles } \\
\text { phosphate } / \mathrm{g} / \mathrm{min} \text { ) }\end{array}$ & 4.2 & 4.8 \\
\hline $\begin{array}{l}\text { Amylo- } 1,6 \text {-glucosidase }(\% \text { glucose } \\
\text { incorporated } / \mathrm{g} / \mathrm{hr} \text { ) }\end{array}$ & 12.4 & 15.6 \\
\hline
\end{tabular}

\section{GLYCOGEN METABOLISM IN THE MUSCLE}

Muscle phosphorylase kinase activity was measured both by activation of endogenous phosphorylase $b$ (Fig. 5) or by activation of exogenous phosphorylase $b$ (Fig. 1B). By both methods, the activity of the enzyme was found to be $25 \%$ of normal. The activity of phosphorylase $a$ in the muscle of $\mathrm{H}$. M. was about $30 \%$ compared to the control activity (zero time in Fig. 5). The ratio between the activity of phosphorylase kinase at $\mathrm{pH} 8.6$ to 6.8 was 1.5 in the control muscle and 1.9 in H. M.'s muscle (Fig. $3 B$ ).

\section{INVESTIGATION OF THE FAMILY}

Glycogen concentration and phosphorylase kinase activity were measured, both in liver and in muscle biopsies of other members of the family. Two sisters of H. M. showed similar high glycogen concentration and low phosphorylase kinase activity, whereas one brother had normal liver glycogen and phosphorylase kinase activity (Table 3 ).

\section{DISCUSSION}

The phosphorylase kinase deficiency in liver of $\mathrm{H}$. M. was pronounced when exogenous phosphorylase $b$ was used as substrate, whereas the activation of endogenous substrate with ATP$\mathrm{Mg}$ was normal (Figs. $1 A$ and 2 ). An explanation to the liver activation of endogenous phosphorylase $b$ in concentrated homogenate of $\mathbf{H}$. M. is that in the experimental conditions the activity of H. M.'s phosphorylase kinase is about $100 \mu$ moles per $50 \mathrm{mg}$ tissue per $5 \mathrm{~min}$. Therefore, it is not surprising that in the shortest period in which phosphorylase kinase activation was examined in concentrated liver homogenate, namely $5 \mathrm{~min}$, full activation had already occurred. This finding may explain the fact that the patient reacted in a normal fashion to glucagon administration. Similar observations were made in most cases of deficiency of phosphorylase or its activation system (19).

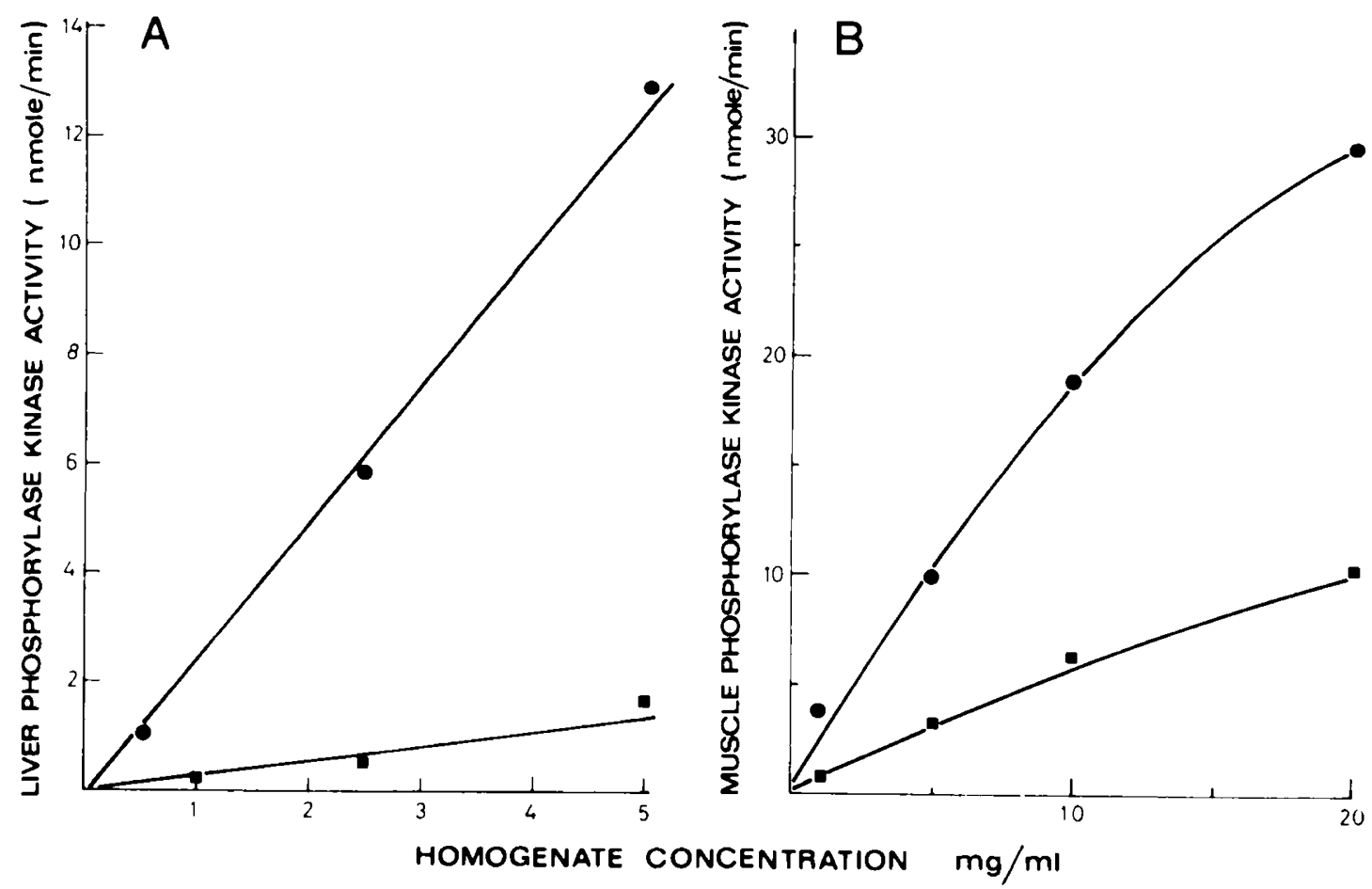

Fig. 1. Liver and muscle phosphorylase kinase activity as a function of homogenate concentration. Phosphorylase kinase activity on exogenous phosphorylase $b$ was measured as described in "Patients and Methods" with various homogenate concentrations (wet weight). $A$, liver; $B$, muscle. $\square$, $\mathrm{H}$. M.: 9 , control 


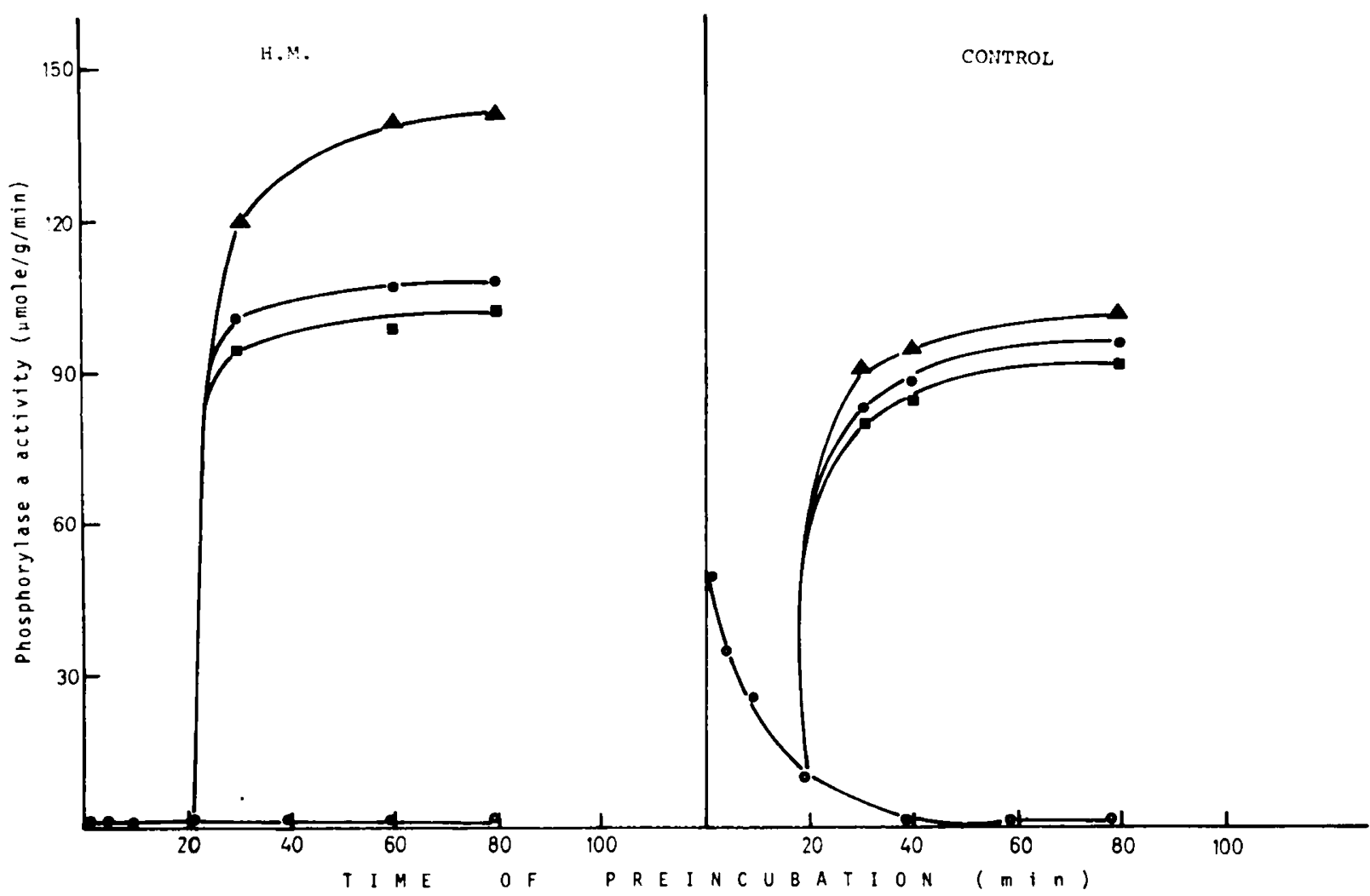

Fig. 2. Inactivation and activation of liver phosphorylase. Fifty $\mathrm{mg}$ of liver were homogenated in $1 \mathrm{ml}$ of ice cold glycylglycine, $100 \mathrm{mM}, \mathrm{pH} 7.4$. The homogenates were incubated at $20^{\circ} \mathrm{C}(\mathrm{O})$. After $20 \mathrm{~min}, 6 \mathrm{mM}$ ATP and $10 \mathrm{mM}$ magnesium acetate were added alone ( $)$ plus $0.1 \mathrm{mM}$ cyclic AMP (Ө) or plus $0.1 \mathrm{mM}$ cyclic AMP and 10 units of phosphorylase kinase ( $\mathbf{\Delta}$ ). Phosphorylase $a$ activity was measured at the time indicated as described in "Patients and Methods."
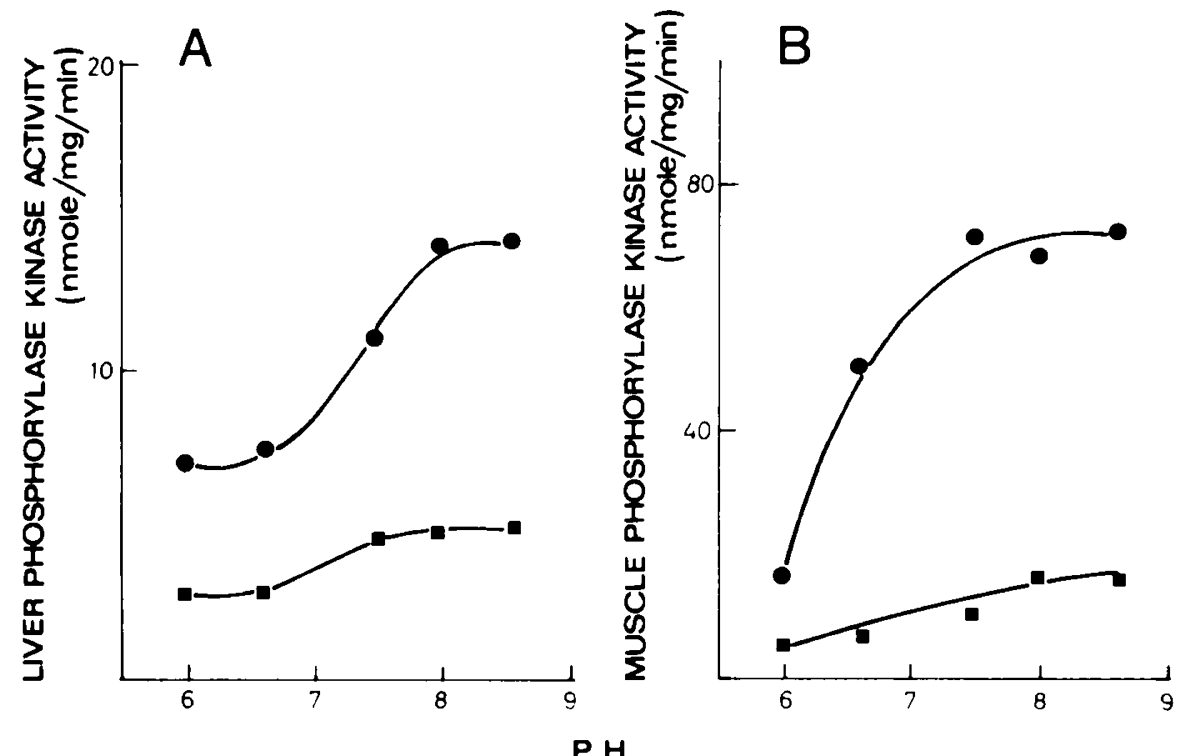

Fig. 3. Liver and muscle phosphorylase kinase activity as a function of $\mathrm{pH}$. Phosphorylase kinase activity was measured in different $\mathrm{pH}$ values as described in "Patients and Methods." $A$, liver; $B$, muscle. $\square$, H. M.; control.

In muscle, the activity of phosphorylase kinase measured using endogenous or exogenous phosphorylase $b$ was very low. In spite of the low activity of muscle phosphorylase kinase, no clinical evidence of myopathy was found.
Both muscle and liver phosphorylase kinase activities of the patient were reduced in similar proportions to normal over the $\mathrm{pH}$ range from 6.8 to 8.2 . These results suggest that the defect resides in the phosphorylase kinase enzyme itself and not in its 


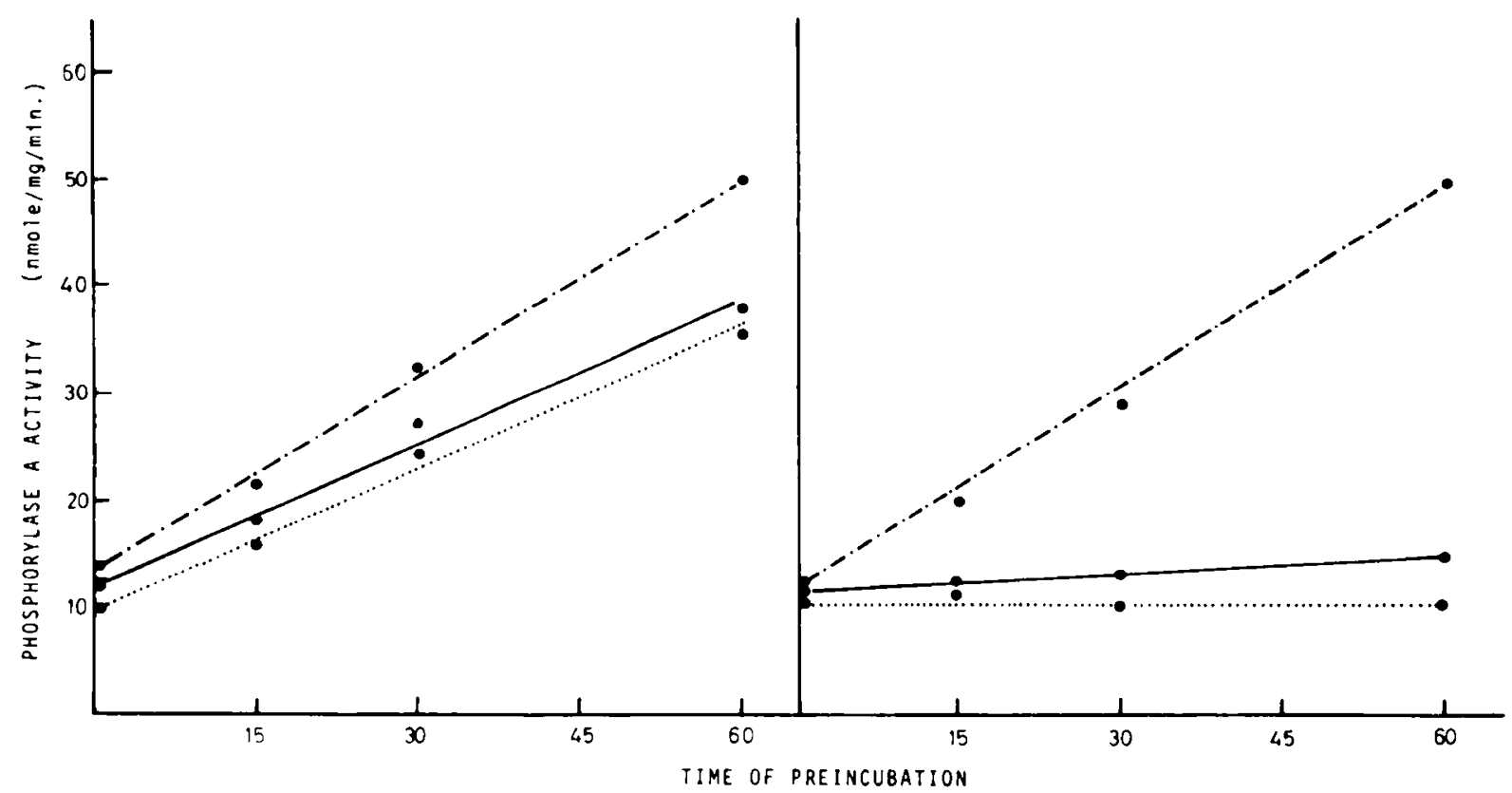

Fig. 4. Activation of exogenous phosphorylase $b$ by liver homogenate in the absence or presence of purified phosphorylase kinase or cyclic AMPdependent protein kinase. Phosphorylase $a$ activity was measured in liver homogenates $(5 \mathrm{mg} / \mathrm{ml})$ in the presence of ATP-Mg at $\mathrm{pH} 8.6(\bullet \ldots)$ ), no addition, (-) addition of 30 units exogenous protein kinase, (-..-) addition of 20 units phosphorylase kinase.

Table 2. Activity of phosphorylase kinase in mixture of homogenates from patient and control subject

\begin{tabular}{|c|c|c|c|c|}
\hline \multicolumn{2}{|c|}{ Protein added $(\mu \mathrm{g})$} & \multicolumn{2}{|c|}{ Activity ( $\mu \mathrm{mole} / \mathrm{mg} / \mathrm{min})$} & \multirow[b]{2}{*}{$\begin{array}{l}\% \text { found/ } \\
\text { calculated }\end{array}$} \\
\hline Control & $\begin{array}{l}\text { Patient } \\
\text { (H. M.) }\end{array}$ & Found & Calculated & \\
\hline 100 & & 10 & & \\
\hline 75 & 25 & 8 & 7.5 & 107 \\
\hline 50 & 50 & 5.2 & 5 & 96 \\
\hline \multirow[t]{2}{*}{25} & 75 & 2.6 & 2.5 & 96 \\
\hline & 100 & 0 & & \\
\hline
\end{tabular}

activating system (5). To our knowledge, the only case published in the past in whom both liver and muscle phosphorylase kinase were, affected is that described by Hug et al. (13). On the basis of his findings, these authors concluded that the reduced phosphorylase kinase activity was due to a defect in cyclic AMP-dependent protein kinase. In contrast to Hug's patient, our case showed normal protein kinase activity, and the addition of purified protein kinase had no effect on the activation of phosphorylase $b$ (Fig. 4; Table 1).

In the X-linked recessive form of phosphorylase kinase deficiency, the liver enzyme is deficient whereas the muscle is normal $(9,10,13,15,16)$.

The family reported here is unusual because phosphorylase kinase was deficient both in liver and muscle and male and female members were affected, suggesting an autosomal recessive mode of inheritance.

The variability of expression of this defect in different families may be related to the fact that phosphorylase kinase is composed of four subunits $(1,2)$, which may be coded on different chromosomes. Different mutations may affect alternate subunits, leading to a variability of expression both in terms of the tissue affected and mode of inheritance.

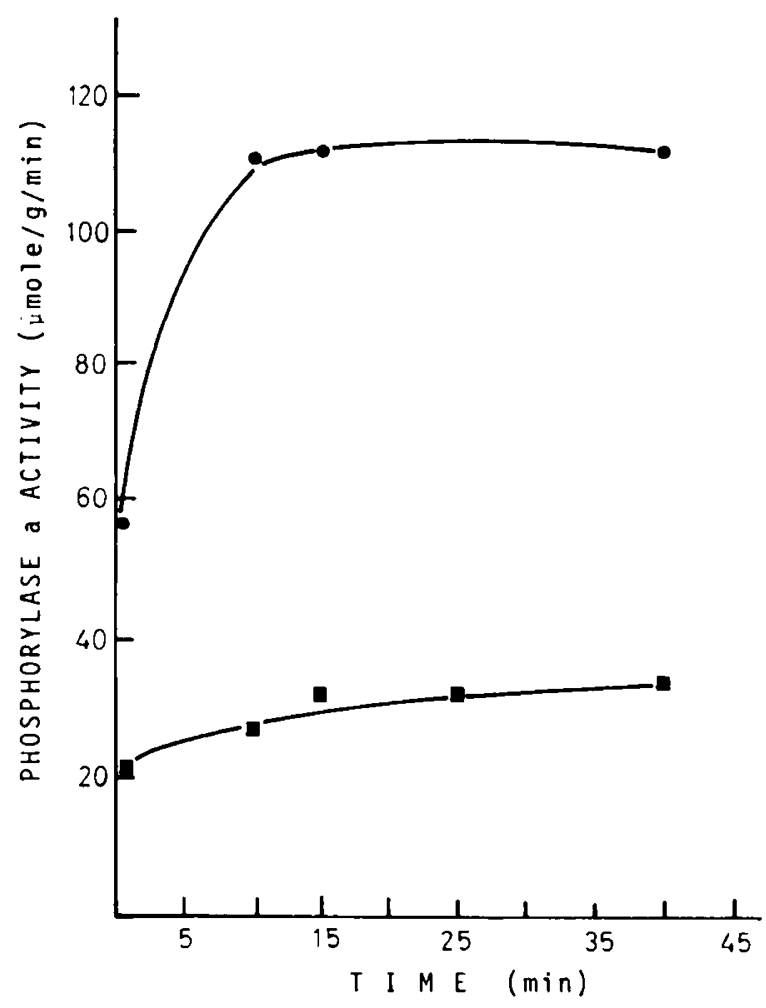

Fig. 5. Conversion of endogenous phosphorylase $b$ to phosphorylase $a$ in muscle homogenate. Muscle $(100 \mathrm{mg} / \mathrm{ml})$ was homogenized in ice-cold $100 \mathrm{mM}$ glycylglycine buffer, $\mathrm{pH}$ 7.4. The homogenate was incubated at $30^{\circ} \mathrm{C}$ in the presence of $40 \mathrm{mM}$ Tris-sodium glycerophosphate, $100 \mathrm{mM}$ ATP. $6 \mathrm{mM} \mathrm{Mg}$ acetate; $20 \mathrm{mM} \mathrm{NaF}$ at pH 8.6. At the time intervals indicated, phosphorylase activity was determined in aliquots of the reaction mixture. control muscle; H. M. muscle. 
Table 3. Liver and muscle glycogen concentration and phosphorylase kinase activity in different members of the family

\begin{tabular}{|c|c|c|c|c|c|c|}
\hline & \multirow[b]{2}{*}{ Sex } & \multirow[b]{2}{*}{ Birth date } & \multicolumn{2}{|c|}{ Liver } & \multicolumn{2}{|c|}{ Muscle } \\
\hline & & & Glycogen \% & $\begin{array}{c}\text { Phosphorylase ki- } \\
\text { nase activity } \\
(\mu \text { moles } / \mathrm{g} / \mathrm{min})\end{array}$ & Glycogen (\%) & $\begin{array}{c}\text { Phosphorylase kinase } \\
\text { activity ( } \mu \text { moles/g/ } \\
\text { min) }\end{array}$ \\
\hline H. M. & Male & 1975 & 17 & 1.4 & 1.9 & 8.1 \\
\hline A. M. & Female & 1968 & 10 & 3.5 & 2.0 & 3.6 \\
\hline A. $\mathbf{M}$. & Male & 1970 & 3.3 & 10.3 & 0.6 & 36 \\
\hline M. M. & Female & 1973 & 20 & 1.1 & 1.5 & 0.8 \\
\hline Control (5) & & & $1-5$ & $12 \pm 3$ & $0.3-0.8$ & $40 \pm 12$ \\
\hline
\end{tabular}

\section{REFERENCES AND NOTES}

1. Cohen. P. T. W., Burchell, A., and Cohen, P.: The molecular basis of skeletal muscle phosphorylase kinase deficiency. Eur. J. Biochem, 66: 347 (1976).

2. Cohen, P., Burchell, A., Foulkes, J. G., and Cohen, P. T. W.: Identification of the $\mathrm{Ca}^{2+}$ dependent modulator protein as the fourth subunit of rabbit muscle phosphorylase kinase. FEBS Lett., 92: 287 (1978).

3. De Lange. R. J., Kemp, R. G.. Riley, W. D.. Cooper, R. A., and Krebs, E. G.: Activation of skeletal muscle phosphorylase kinase by adenosine triphosphate and adenosine 3'5' monophosphate. J. Biol. Chem.. 243: 2200 (1968).

4. De Wulf, H., Stalmans, W., and Hers, H. G.: The influence of inorganic phosphate, adenosine triphosphate and glucose-6-phosphate on the activity of liver glycogen synthetase. Eur. J. Biochem., 6: 545 (1968).

5. Fernandes, J., Koster, J. F., Grose, W. F. A.. and Sorgedrager, N.: Hepatic phosphorylase deficiency. Its differentiation from other glycogenoses. Arch. Dis. Child.. 49: 186 (1974).

6. Gorin, E., and Rosenblum, S.: Effect of triamcinolone treatment, starvation and diabetes on rat liver protein kinase activity. Biochim. Biophys. Acta, 343: 510 (1974).

7. Gross, S. R., and Mayer. S. E.: Characterization of the phosphorylase $b$ to $a$ converting activity in skeletal muscle extract of mice with the phosphorylase $h$ kinase deficiency mutation. J. Biol. Chem., 249: 6710 (1974).

8. Hers, H. G.: Etudes enzymatique sur fragments hepatiques: application a la classification des glycogenoses. Rev. Int. Hepatol., 9: 35 (1959).

9. Howell, R. R.: The glycogen storage disease In: J. B. Stanbury, J. B. Wyngarden. D. S. Fredrickson: The Metabolic Basis of Inherited Disease. p. 149 (McGraw Hill Book Co., New York, 1972).

10. Hug, G.. Garancis, J. C.. Schubert, W. K.. and Kaplan, S.: Glycogen storage disease types II, III, VIII, and IX. Am. J. Dis. Child., 3: 457 (1966).

11. Hug, G., Schubert, W. K., and Chuck, G.: Phosphorylase kinase of the liver: deficiency in a girl with increased hepatic glycogen. Science (Wash. D. C.) 153: 1534 (1966).

12. Hug. G., Schubert, W. K., and Chuck, G.: Deficient activity dephosphorylase kinase and accumulation of glycogen in the liver. J. Clin. Invest.. 48: 704 (1969).

13. Hug. G., Schubert. W. K., and Chuck. G.: Loss of cyclic 3'5' AMP dependent kinase and reduction of phosphorylase kinase in skeletal muscle of a girl with deactivated phosphorylase and glycogenosis of liver and muscle. Biochem. Biophys. Res. Commun., 40: $982(1970)$.

14. Huijing, F.: Phosphorylase kinase in leucocytes of normal subjects and of patients with glycogen storage disease. Biochim. Biophys. Acta. 148: 601 (1967).
15. Huijing, F.: Glycogen storage disease type VI a: low phosphorylase kinase activity caused by a low enzyme substrate affinity. Biochim. Biophys. Acta, 206: 199 (1970).

16. Huijing, F., and Fernandes. J.: X chromosomal inheritance of liver glycogenosis with phosphorylase kinase deficiency. Am. J. Hum. Genet., 21: 275 (1969).

17. Johnson. J. A.. Nash. J. D., and Fusaro, R. M.: An enzymic method for the quantitative determination of glycogen. Anal. Biochem., 5: 370 (1963).

18. Krebs. E. G.: Phosphorylase $b$ kinase from rabbit muscle. Methods Enzymol., 8 : 543 (1966).

19. Krebs, E. G.. De-Lange, R. S., Kemp, R. G.. and Reley, W. D.: Activation of skeletal muscle phosphorylase. Pharmacol. Rev., /8: 163 (1966).

20. Lederer. B.. Van-Hoof, F., Van Den Berghe, G., and Hers, H. G.: Glycogen phosphorylase and its converter enzymes in hemolysates of normal human subjects and of patients with type IV glycogen storage disease. A study of phosphorylase kinase deficiency. Biochem. J., 147: 23 (1975).

21. Morishita. Y., Nishijama, K.. Yamamura. H.. Kodama, S., Negishi, H., Matsuo. M., Matsuo, T., and Nishizuka, V.: Glycogen phosphorylase kinase deficiency: a survey of enzymes in phosphorylase activating system. Biochem. Biophys. Res. Commun., 54: 833 (1973).

22. Schimke, R. N., Zakheim, R. M., Corder, R. C., and Hug. G.: Glycogen storage disease type IX: benign glycogenosis of liver and hepatic phosphorylase kinase deficiency. J. Pediatr., 83: 1031 (1973).

23. Stalmans, W., De-Wulf, H.. Lederer. B., and Hers, H. G.: The effect of glucose and of a treatment by glucocorticoids on the inactivation in vitro of liver glycogen phosphorylase. Eur. J. Biochem., 15: 9 (1970).

24. Steinitz, K.: Laboratory diagnosis of glycogen disease In H. Sobota, C. P. Stewart: Advances in Clinical Chemistry. Vol. 9. p. 227 (Academic Press Inc., New York, 1967).

25. Part of this study was presented to the American Pediatric Society, 1979, and appeared as an abstract in Pediatric Research (23).

26. Dr. H. G. Hers and his group recently published another case in whom liver and muscie phosphorylase kinase activity were deficient, which was subsequently published in Lederer, B, Van de Werne, G., De Barsy, T. H., and Hers, H. G.: The autosomal form of phosphorylase kinase deficiency in man: reduced activity of the muscle enzyme. Biochem. Biophys. Res. Commun., a2: 169 (1980).

27. Requests for reprints should be addressed to: Dr. Shimon W. Moses. Professor and Chairman. Division of Pediatrics. Soroka Medical Center, P.O.B. 151. Beer-Sheba, Israel.

28. Received for publication January 23, 1980

29. Accepted for publication July $15,1980$. 